JURNAL RESPIRASI

JR

Vol. 6 No. 1 January 2020

\title{
Exhaled Carbon Monoxide Levels of Scavengers in Bantargebang Landfill, Bekasi
}

\author{
Agus Dwi Susanto*, Dita Kurnia Sanie, Fahrial Harahap \\ Department of Pulmonology and Respiratory, Faculty of Medicine, Universitas Indonesia - Persahabatan Hospital, Jakarta, \\ Indonesia
}

\begin{abstract}
Background: The scavengres in the landfill have high risk pollution exposure. Carbonmonoxide (CO) is one of important pollutant produced by burning process. Exhaled $\mathrm{CO}$ level in scavenger predicted increase cause by exposure pollution in workplace area. There has been no data on exhale CO in scavengers, especially in Bantar Gebang, Bekasi. Methods: This study used a crosssectional design to the scavengers who work and live in Ciketing Udik, Bantargebang, Bekasi. Conducted in January-March 2015, doing interview with questionnaires, and exhaled carbonmonoxide (CO) test. Results: Total sample was 108 subjects. Exhaled CO test result was 46 subjects $(42.6 \%)$ had exhaled CO 5-10 ppm, 36 subjects $(33.3 \%)>10$ ppm and 26 subjects $(24.1 \%) \leq 4$ ppm. Multivariate analysis between exhaled CO levels with subject characteristic found smoking habits was significantly correlated with exhaled CO levels $(\mathrm{p}=0,000)$. Conclusion: There was 33.3\% scavengers had exhaled CO > $10 \mathrm{ppm}$. Smoking habits is the only factor that significantly correlated with exhaled $\mathrm{CO}$ in scavenger
\end{abstract}

Keywords: scavengers, carbon monoxide exhalation, pollution exposure

Correspondence: Agus Dwi Susanto, Department of Pulmonology and Respiratory, Faculty of Medicine Universitas Indonesia/ Persahabatan Hospital. J1. Persahabatan Raya 1, Rawamangun, Jakarta Timur 13230. E-mail: agus_ds2000@ yahoo.com

\section{INTRODUCTION}

Waste disposal at the final landfill location is increasingly causing concern for the health of the population living nearby, especially with hazardous waste being disposed of. Studies on health as a result of the disposal site have been carried out, especially in North America. ${ }^{1}$ Sanitation workers, especially garbage collectors in urban areas, are one of the occupations that posed high risk to health and safety. Increased volume, influx of hazardous waste streams, manual handling of waste, inadequate personal protective equipment (PPE), lack of awareness about health, poor sanitation, and poor environmental management at landfill sites expose workers to environment and hazardous work. Eventhough the incidence and prevalence of hazards at waste sector workers are increasing, very little research has been done in developing countries. Much research was carried out in developed countries, but the data cannot be directly extrapolated for developing countries $^{2,3}$

There have been reported occupational health hazards associated with handling waste including skin, eyes, and respiratory system infections, accidents such as bone and muscle disorders resulting from handling heavy containers, wound infections due to contact with sharp objects, poisoning and chemical burns due to contact with a small amount of hazardous chemical waste mixed with general waste, and other injuries due to workplace accidents at landfills or due to methane gas explosions at landfill sites. ${ }^{4}$ Based on research conducted by Abdou, there were four major health problems due to working at landfill, including respiratory infections and/ or allergies (65.5\%), eye infections (48.3\%), gastrointestinal infections (20.7\%), and musculoskeletal injuries (17.2\%). ${ }^{9}$ A study in Karachi, Pakistan, showed that diseases that arises including tuberculosis (TB), gastric problems, respiratory problems, skin infections, and ulcers. ${ }^{5}$

Workers in a landfill have a significantly higher prevalence to upper and lower airway disorders and they were more often suffer from diarrhea, fungal infections, skin ulceration, burning sensation in the extremities, tingling or numbness, temporary memory loss, and depression. ${ }^{6}$ Another study in Delhi, India in 1995, reported that workers in landfills and plant incineration have an increased risk of lung and digestive disorders. ${ }^{7}$ The gas in the landfill consists of a mixture of different gases, including methane (45\%-60\%) and carbon dioxide $(40 \%-60 \%)$. Gas in the landfill also includes small amounts of nitrogen, oxygen, ammonia, sulfide, 
hydrogen, carbon monoxide (CO), and nonmethane organic compounds (NMOCs) such as trichlorethylene, benzene and vinyl chloride. 8 These gases also have an impact on the health of workers at the landfill especially pulmonary health problems.

The aim of this study was to obtain data on levels of exhaled air $\mathrm{CO}$ in scavengers in Bantar Gebang Landfill and the factors that influence it.

\section{METHODS}

This study used a cross sectional study design. This research was part of a research on respiratory disorders and pulmonary function in the scavengers in Bantar Gebang Landfill, Bekasi. The place of research was rukun tetangga (RT) 01/05, Ciketing Udik subdistrict, Bantar Gebang, Bekasi. The study was conducted in January - March 2015. The sample of the study was all the scavengers living in the Ciketing Udik sub-district, Bantar Gebang, Bekasi and fulfilling the research criteria. The minimum total sample needed was 97 subjects, rounded to 100 subjects.

The sampling technique was done by consecutive sampling in which every affordable population that meets the research criteria was included as a sample to meet the required sample size. The inclusion criteria were male and female, >14 years old, were able to perform the lung function test and exhaled air $\mathrm{CO}$ examination properly, signed the consent form and were willing to complete the research procedures. The samples were excluded if the spirometry examination was not acceptable and was not reproducible. Subjects were given a basic questionnaire and underwent spirometry examination and exhaled air $\mathrm{CO}$ examination. The basic questionnaire including respondent's identity data and sociodemographic data. Exhaled air CO levels were measured using the Bedfont piCO+TM Smokerlyzer ${ }^{\circledR}$ device. Data on the content of air pollutant gases including $\mathrm{CO}$ levels in the air were obtained from the examination results of the Jakarta City Provincial Regional Environmental Management Department (Badan Pengelolaan Lingkungan Hidup Daerah). This research was approved by Ethics Committee of the Faculty of Medicine, Universitas Indonesia.

\section{RESULTS}

This research was conducted on scavengers who live and work in the Bantar Gebang Landfill (Integrated Waste Disposal) environment, Bekasi. Samples collected were 120 samples. Of the 120 samples, only 108 samples met the study criteria.

Table 1. Exhaled Air CO Levels

\begin{tabular}{lcc}
\hline Exhaled air CO levels & $\mathrm{n}$ (subjects) & Percentage $(\%)$ \\
\hline$\leq 4 \mathrm{ppm}$ & 26 & 24.1 \\
$5-10 \mathrm{ppm}$ & 46 & 42.6 \\
$>10 \mathrm{ppm}$ & 36 & 33.3 \\
\hline
\end{tabular}

\section{Characteristics of the Subjects}

Characteristics of the subjects consisted of gender, age group, nutritional status, education level, smoking habits, distance of the house, exposure duration and work duration. In this study, most subjects were female which were 80 subjects $(74.1 \%)$ while male subjects were only 28 subjects (25.9\%). The age of research subjects consisted of 15-35 years as many as 51 subjects $(47.2 \%)$ and $>35$ years as many as 57 subjects $(52.8 \%)$. Body mass index (BMI) of the subjects were normal category in 60 subjects $(55.6 \%)$, less in 10 subjects, overweight in 31 subjects, and obesity in 7 subjects. The education level of subjects were 21 subjects $(19.4 \%)$ never attend formal education, 78 subjects $(72.2 \%)$ graduated from Elementary Schools, 7 subjects $(6.5 \%)$ graduated from Junior High Schools, and 2 subjects (1.9\%) graduated from Senior High Schools. Based on smoking habits, subjects were found to be nonsmokers in 75 subjects $(69.4 \%)$ and smokers in 33 subjects $(30.6 \%)$. The distance between the house and landfill was 81 subjects $(75 \%) \leq 200$ meters and 27 subjects $(25 \%)>200$ meters. Based on the work duration, subjects were divided into $\leq 10$ years in 49 subjects $(45.4 \%)$ and $>10$ years in 59 subjects $(54.6 \%)$. The exposure duration/day is divided into 1-6 hours/day in 48 subjects $(44.4 \%)$ and $>6$ hours/day in 60 subjects (55.6\%). All 108 subjects (100\%) did not use PPE.

\section{Exhaled air CO levels}

Exhaled air $\mathrm{CO}$ examination results have an abnormal distribution with a median value was $7 \mathrm{ppm}$, the lowest value was $2 \mathrm{ppm}$ and the highest value was 23 ppm. While the $\mathrm{COHb}$ results obtained a median value of $1.8 \%$ with the lowest value was $1 \%$ and the highest value was $4.4 \%$. Exhaled air $\mathrm{CO}$ of $\leq 4 \mathrm{ppm}$ was found in 26 subjects $(24.1 \%), 5-10 \mathrm{ppm}$ was found in 46 subjects $(42.6 \%)$ and $>10 \mathrm{ppm}$ was found in 36 subjects $(33.3 \%)$. The distribution of subjects based on exhaled air CO examination can be seen in Table 1 .

\section{Pollutant levels from samples of airborne particles}

Data on air analysis was obtained through inspection by Jakarta City Provincial Regional Environmental Management Department. The examination was carried out for 4 times on different days (Test results 1,2,3 and 4, as can be seen in Table 2). Based on data from Jakarta City Provincial Regional Environmental Management Department, the air quality at Bantar Gebang Landfill was still below the quality standard threshold.

Table 2. Samples of Air Particles

\begin{tabular}{|c|c|c|c|c|c|c|}
\hline \multicolumn{3}{|c|}{ Parameters Denomination } & \multicolumn{3}{|c|}{ Test results } & \multirow{2}{*}{$\begin{array}{c}\text { Quality } \\
\text { Standard } \\
\text { Threshold }\end{array}$} \\
\hline & & $\overline{1}$ & 2 & 3 & 4 & \\
\hline $\mathrm{NO}_{2}$ & $\mathrm{ug} / \mathrm{Nm}^{3}$ & $<10$ & 14.3 & 15.1 & 19 & 400 \\
\hline $\mathrm{SO}_{2}$ & $\mathrm{ug} / \mathrm{Nm}^{3}$ & $<27$ & 34.1 & 31.6 & $<27$ & 900 \\
\hline $\mathrm{H}_{2} \mathrm{~S}$ & $\mathrm{ug} / \mathrm{Nm}^{3}$ & $<8$ & $<8$ & $<8$ & $<8$ & 35 \\
\hline $\mathrm{NH}_{3}$ & $\mathrm{ug} / \mathrm{Nm}^{3}$ & 45.5 & 95.5 & 86.3 & 93.6 & 100 \\
\hline $\mathrm{CO}$ & $\mathrm{ug} / \mathrm{Nm}^{3}$ & 342 & 342 & 1026 & 570 & 30000 \\
\hline TSP & $\mathrm{ug} / \mathrm{Nm}^{3}$ & 134 & 271 & 71 & 125 & 230 \\
\hline $\mathrm{Pb}$ & $\mathrm{ug} / \mathrm{Nm}^{3}$ & 0.03 & 0.14 & 0.03 & 0.02 & 1 \\
\hline
\end{tabular}


Table 3. Relationship Between Subject Characteristics and

\begin{tabular}{|c|c|c|}
\hline \multicolumn{3}{|c|}{ Carbon Monoxide (CO) Levels of Exhaled Air } \\
\hline Variable & $\begin{array}{l}\text { Carbon monoxide } \\
\text { exhalation levels } \\
\text { Median (Min-Max) }\end{array}$ & p-value \\
\hline \multicolumn{3}{|l|}{ Gender } \\
\hline Male & $15(4-23)$ & 0.000 \\
\hline Female & $6(2-14)$ & \\
\hline \multicolumn{3}{|l|}{ Age } \\
\hline $15-35$ years old & $6(2-21)$ & 0.058 \\
\hline$>35$ years old & $7(2-23)$ & \\
\hline \multicolumn{3}{|l|}{ Education Level } \\
\hline Uneducated & $6(2-23)$ & 0.409 \\
\hline Formal education & $7(2-22)$ & \\
\hline \multicolumn{3}{|l|}{ Nutritional status } \\
\hline Normal & $7(2-23)$ & 0.074 \\
\hline Abnormal & $7(2-21)$ & \\
\hline \multicolumn{3}{|l|}{ Smoking habits } \\
\hline Nonsmokers & $6(2-14)$ & 0.000 \\
\hline Smokers & $15(4-23)$ & \\
\hline \multicolumn{3}{|l|}{ House distance } \\
\hline$\leq 200$ meters & $7(2-23)$ & 0.743 \\
\hline$>200$ meters & $7(2-21)$ & \\
\hline \multicolumn{3}{|l|}{ Exposure duration } \\
\hline 1-6 hours & $7(2-19)$ & 0.007 \\
\hline$>6$ hours & $11(2-23)$ & \\
\hline \multicolumn{3}{|l|}{ Work duration } \\
\hline$\leq 10$ years & $7(2-21)$ & 0.294 \\
\hline$>10$ years & $7(2-23)$ & \\
\hline
\end{tabular}

*Fisher test

\section{Relationship between subject characteristics and exhaled air CO levels}

Analysis of exhaled air $\mathrm{CO}$ levels with independent variables, including age, gender, education level, nutritional status, smoking habits, exposure duration, house distance, and work duration was done with the Mann Whitney test. The results of the analysis of exhaled air CO levels on age categories $(p=0.058)$, education $(\mathrm{p}=0.409)$, nutritional status $(\mathrm{p}=0.074)$, house distance $(p=0.743)$ and work duration $(p=0.294)$ have no statistically significant relationship $(\mathrm{p}>0.05)$. Only gender $(p=0.000)$, smoking habits $(p=0.000)$, and exposure duration $(\mathrm{p}=0.007)$ had a significant relationship with exhaled air CO levels (Table 3).

Further multivariate analysis of exhaled air $\mathrm{CO}$ levels were performed on independent variables with $\mathrm{p}<0.25$, including age, nutritional status/BMI, gender, exposure duration and smoking habits (Table 4). The results of the linear regression analysis showed that the variables that were significantly related to the exhaled air $\mathrm{CO}$ levels were gender and smoking habit variables ( $\mathrm{p}=0.015$ and $\mathrm{p}=0.000$, respectively). Correlation analysis result on gender and smoking habit variables were -0.302 and -0.504 thus an adjusted R2=0.636 was obtained. In other words, gender and smoking habit affected the exhaled air CO levels by $63.6 \%$ and the remaining were influenced by other variables.

\section{DISCUSSION}

This research was conducted with the aim of understanding the levels of exhaled air $\mathrm{CO}$ in scavengers
Table 4. Linear Regression Analysis of Carbon Monoxide Exhalation Levels

\begin{tabular}{lcc}
\hline Variable & $\mathrm{R}$ & $\mathrm{p}$-value \\
\hline Age & 0.022 & 0.717 \\
BMI & 0.060 & 0.319 \\
Exposure duration & -0.083 & 0.224 \\
Gender & -0.302 & 0.015 \\
Smoking habits & -0.504 & 0.000 \\
\hline
\end{tabular}

working at Bantar Gebang Landfill. Exhaled air CO examination results in this study obtained a median value of $7 \mathrm{ppm}$ with the lowest value was $2 \mathrm{ppm}$ and the highest value was $23 \mathrm{ppm}$. The largest percentage of exhaled air CO was at $5-10$ ppm as many as 46 subjects (42.6\%), followed by $>10$ ppm as many as 36 subjects $(33.3 \%)$ and $\leq 4$ ppm as many as 26 subjects $(24.1 \%)$.

Exhaled air $\mathrm{CO}$ levels have long been used extensively in assessing a person's smoking status indicator. ${ }^{9}$ Exhaled air CO levels are also a potential biomarker associated with outdoor air pollution exposure. ${ }^{10}$ Research conducted by Maga et al., who assessed the effect of air pollution and smoking habits on exhaled air CO levels, found that in nonsmokers, higher levels of exhaled air $\mathrm{CO}$ were found in subjects living in large-city areas compared to smaller cities. ${ }^{11}$ In this study, analysis of exhaled air CO levels on gender, smoking habits, and exposure duration had a significant relationship. The relationship of exhaled air CO levels to gender cannot be concluded because the majority of subjects were women who mostly do not smoke thus it can cause bias. Based on multivariate analysis, it was found that the variables that correlated significantly with exhaled air $\mathrm{CO}$ levels were smoking habit variable $(p=0.000)$. The results of the study were in accordance with research by Inayatillah et al., which found that exhaled air $\mathrm{CO}$ levels in smokers were higher than nonsmokers. ${ }^{12}$ Research by Maga et al., assessed the effect of air pollution and smoking habits on exhaled air $\mathrm{CO}$ levels and also found that exhaled air CO levels in smokers were higher than nonsmokers. ${ }^{11}$

Based on air sample data, the CO levels of the Bantar Gebang Landfill environment were still below the quality standard threshold value. Therefore, the increase in exhaled air $\mathrm{CO}$ levels in subjects was more due to their smoking habit and did not because of exposure at work. This was also causing the distance between home and work duration did not have a significant relationship with exhaled air CO levels. This research data was in accordance with the literature which showed that the air CO gas levels in landfills area were very little. ${ }^{8}$

The habit of smoking in scavengers in this study was closely related to exhaled air CO levels. Smoking habits at work have a high risk of respiratory disorders in workers. According to Mustajbegovic et al., smoking has a close relationship with respiratory disorders in the workplace. ${ }^{13}$ Research conducted by Eisner et al., also supported that smoking was a risk factor that can cause health problems in the workplace. ${ }^{14}$ 


\section{CONCLUSION}

A total of 36 scavengers subjects $(33.3 \%)$ had high levels of exhaled air $\mathrm{CO}$ which were above $10 \mathrm{ppm}$. Exhaled air $\mathrm{CO}$ level in scavengers was not associated with exposure to pollutants at work but was significantly related to smoking habits

\section{REFERENCES}

1. Vrijheid M. Health effects of residence near hazardous waste landfill sites: a review of epidemiologic literature. Envir Health Perspect.2000;108:101-12.

2. Roopa S, Padmavathi R, Akolkar A, Sankar S, Ravishankar P, Vijayalakshmi $\mathrm{T}$, et al. Respiratory functions of conservancy workers working in solid waste management sector of Chennai,India. F1000Research. 2013;67:1-6.

3. Abdou MHM. Health Impacts on Workers in Landfill in Jeddah City, Saudi Arabia. J Egypt Public Health Assoc. 2007:82:319-29.

4. United Nations Environment Programme. Health impacts of solid waste. [Online]. 1996.[cited 2013 November 22]. Available from http://edugreen.teri.res.in/ EXPLORE/solwaste/health.htm.

5. Rouse JR. Seeking common ground for people: livelihoods, governance and waste.Habitat Int.2006; 30(4):741-53.

6. Ray MR, Roychoudhury S, Mukherjee G, Roy S, Lahiri T. Respiratory and general health impairments of workers employed in a municipal solid waste disposal at an open landfill site in Delhi. Int J Hyg Environ Health. 2005; 208(4):255-62.
7. Oulsen OM, Breum NO, Ebbehøj N, Hansen AM, Ivens UI, Van Lelieveld D, et al. Sorting and recycling of domestic waste. Review of occupational health problems and their possible causes. Sci Total Environ.1995;168(1):

8. Agency for Toxic Substances and Disease Registry. Landfill gas primer : an overview for environmental health professionals. [Online]. 2001 [cited 2013 December 03]. Available from: http://www.atsdr.cdc. gov/ HAC/landfill/html/ch1.html.

9. Middleton ET, Sci BM, Morice AH. Breath Carbon Monoxide as an Indication of Smoking Habit. Chest 2000;117:758-763.

10. Lawin H, Fanou LA, Hinson V, Wanjiku J, Ukwaja NK, Gordon SB. Exhaled carbon monoxide: a noninvasive biomarker of short-term exposure to outdoor air pollution. BMC Public Health. 2017; 17: 320.

11. Maga M, Janik MK, Wachsmann A, Chrząstek-Janik O, Koziej M, Bajkowski M. Influence of air pollution on exhaled carbon monoxide levels in smokers and nonsmokers. A prospective cross-sectional study.Environ Res. 2017;152:496-502

12. Inayatillah IR, Syahrudin E, Susanto AD. Kadar Karbon Monoksida Udara Ekspirasi pada Perokok dan Bukan Perokok serta Faktor-Faktor yang Mempengaruhi. J Respir Indo. 2014; 34: 180-90.

13. Mustajbegovic J, Zuskin E, Schachter EN. Respiratory findings in chemical workers exposed to low concentrations of organic and inorganic air pollutants. Am J Ind Med.2000;38:431-40.

14. Eisner MD, Yelin EH, Katz PP. Risk factors for work disability in severe adult asthma.Am J Med.2006; 119:884-91. 